
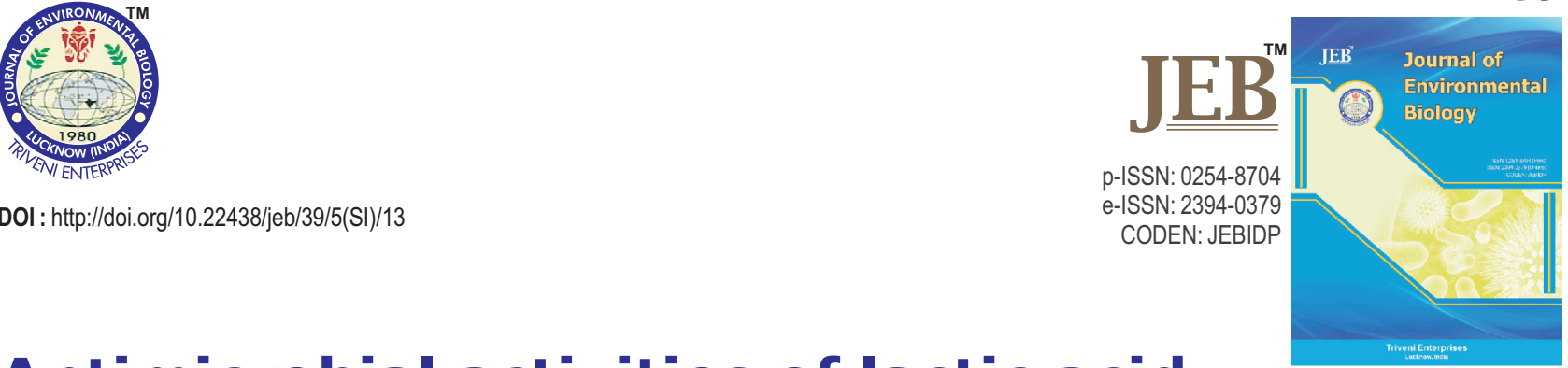

\title{
Antimicrobial activities of lactic acid bacteria isolated from Malaysian prawn, Macrobrachium rosenbergii
}

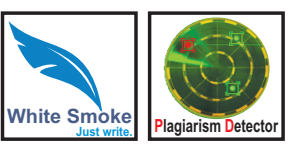

\section{Authors Info}

\section{N.Z. Azahar ${ }^{1 *}$, S. lehata ${ }^{1}$, F. Fadhil $^{1}$, M. Bulbul ${ }^{2}$ and Md. A. Kader ${ }^{1,2}$}

${ }^{1}$ School of Fisheries and Aquaculture Sciences, Universiti Malaysia Terengganu, 21030 Kuala Terengganu, Terengganu, Malaysia ${ }^{2}$ Institute of Tropical Aquaculture, Universiti Malaysia Terengganu, 21030 Kuala Terengganu, Terengganu, Malaysia

*Corresponding Author Email : syafiqahzahidahazahar@gmail.com

Key words

16S rDNA Antimicrobial activity Lactic acid bacteria Macrobrachium rosenbergii

Publication Info

Paper received : 08.03.2017 Revised received : 07.06.2017 Re-revised received : 06.07.2017 Accepted : 28.12.2017

\section{Abstract}

Aim: This study aimed to identify lactic acid bacteria (LAB) isolated from Macrobrachium rosenbergii with an emphasis on their antimicrobial activities against pathogens.

Methodology: Six M. rosenbergii broodstocks were collected from local fishermen and brought to the laboratory where all of them were sacrificed and their digestive tracts were collected. Fourteen isolates grew in MRS agar medium and subjected to $\mathrm{pH}$ between $6.3-6.6$ at $37^{\circ} \mathrm{C}$. The strains were tested for their ability to inhibit the growth of pathogens; Vibrio parahaemolyticus, V. alginolyticus and Aeromonas hydrophila. Molecular identification of the strains were performed by amplifying and sequencing the $16 \mathrm{~S}$ rDNA by which the results were then compared to the database of known 16S rDNA sequences.

Results: The results showed that $57 \%$ of the strains inhibited growth against both $V$. alginolyticus and $V$. parahaemolyticus, whereas only $21 \%$ of the strains inhibited growth against all the pathogens tested. The identification result showed that 6 strains had high similarity with Enterococcus faecalis, whereas 4 isolates had high similarity with Lactococcus garviae and 4 isolates were affiliated with Lactococcus lactis.

Interpretation: All strains were identified as lactic acid bacteria, and strains with the best ability to inhibit pathogens will be selected for further studies on their potential as dietary additive.

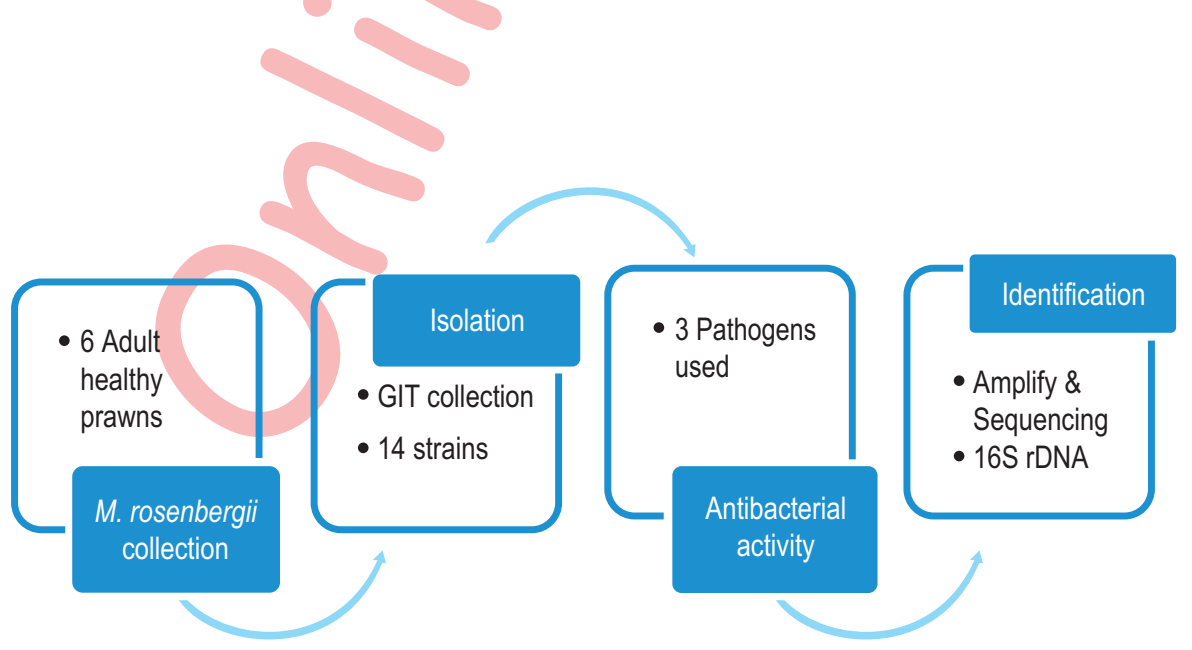




\section{Introduction}

Crustaceans such as prawns, shrimps, lobsters and crabs play an important role in aquaculture and are good protein sources, essential amino acids and polyunsaturated fatty acids (Muralisankar et al., 2014). While the giant freshwater prawn, Macrobrachium rosenbergii is a commercially important species that is currently being farmed throughout the world, but this industry has experienced little growth over the past decade (FAO, 2016). Part of this limited growth include diseases such as Macrobrachium Muscle Virus (MMV), White Spot Syndrome Baculovirus (WSBV) and Idiopathic Muscle Necrosis (IMN) (FAO, 2004-2016).

In the past, farmers had to use large quantities of drugs such as antibiotics in order to improve the prawn survival rates and production, which has led to the emergence of antibiotic resistant bacteria and imbalance of microbiota in the gastrointestinal tract of aquatic species (Nakano, 2007). Therefore, probiotics have been used as an alternative to antibiotics for inhibiting pathogens and diseases in aquaculture species (Cruz et al., 2012). Probiotics comes from the Greek words; 'Pro' and 'bios' which means "for life" (Schrezenmeir and De Vrese, 2001). Probiotics are defined as live microorganisms and can promote beneficial health to the host when they are administered in an appropriate amount (FAO/WHO, 2001). Their mechanisms of actions include competitive exclusion against pathogens, host digestion improvement through production of enzymes, supplying essential nutrients, enhancement of immune response, as well as improving water quality (Balcazar et al., 2006).

There are many criteria to be met while selecting probiotic microorganisms that could confer beneficial health effects to the host. firstly, they should cause no harm to the host, should be accepted by the host via ingestion, should have ability to proliferate and colonize within the host, and should contain no virulent resistance or antibacterial resistance genes (Verschuere et al., 2000; Kesarcodi-Watson et al., 2008). The potential probiotics must be tested with inhibitory activity against pathogens, first in order to access whether they can provide protection to the hosts when exposed to the pathogens (Vijayan et al., 2006; Hai et al., 2007; Irianto and Austin, 2002; Vaseeharan et al., 2004). Therefore, potential probiotics that possess these characteristics are most suitable to be applied to the cultured species in aquaculture.

The objective of the study was to isolate lactic acid bacteria (LAB) strains from gastrointestinal tracts of healthy adult prawn, $M$. rosenbergii, based on their antimicrobial activities against three pathogens.

\section{Materials and Methods}

Source of prawns and bacteria: Adult freshwater prawn $M$. rosenbergii, with an average weight of $10 \mathrm{~g}$ were obtained from Sungai Manir, Kuala Terengganu, Terengganu, Malaysia. MRS agar, Marine agar, Tryptic Soy Agar (TSA), MRS broth and Marine broth were prepared according to manufacturer's instruction (Merck, USA). Both the species of Vibrio (V. alginolyticus and V. parahaemolyticus) were cultivated and maintained in Marine broth. Aeromonas hydrophilla was cultured and maintained in TSA. The incubation temperature was maintained at $37^{\circ} \mathrm{C}$.

Isolation of putative probiotics and determination of antibacterial activity against pathogens : Prawns were washed with $70 \%$ ethanol before dissecting out the intestines using sterile tweezers and scissors. The intestines with digestive contents were weighed and suspended in phosphate buffered saline $(0.01 \mathrm{M}$ phosphate buffer, $0.0027 \mathrm{M}$ potassium chloride, and $0.137 \mathrm{M}$ sodium chloride, $\mathrm{pH} 7.4$ ) to prepare the homogenate by using homogenizer. The suspensions were serially diluted between $10^{-2}$ to $10^{-5}$ for each dilution, and $100 \mu$ of the suspension was sampled and spread onto the surface of MRS agar with $1 \%$ $\mathrm{CaCO}_{3}$. The plates were then incubated under aerobic conditions at $37^{\circ} \mathrm{C}$ for $24-48 \mathrm{hrs}$. A total of 14 isolates were obtained and all of them were tested for antibacterial activity against the following pathogens: A. hydrophilla, V. parahaemolyticus and V. alginolyticus by well diffusion assay. Briefly, after $24 \mathrm{hrs}$ of culturing $V$. parahaemolyticus and $V$. alginolyticus in a marine broth, a sterile cotton swab was dipped into the broth and spread onto marine agar, which was allowed to dry for $20 \mathrm{~min}$. Wells of 5.0 $\mathrm{mm}$ in diameter were punched into the agar with a sterile pipette tip. Each agar plate was punched with 4 wells. All bacterial isolates were cultured in a MRS broth and incubated at $37^{\circ} \mathrm{C}$ for $24 \mathrm{hrs}$, and then $5 \mathrm{ml}$ of broth culture was sampled and centrifuged for 5 min at $10,000 \mathrm{rpm}$. A60 $\mu$ l of supernatant was taken from the tube and added into the well of agar plates loaded with corresponding pathogens. All the plates were incubated for $24 \mathrm{hrs}$ at $37^{\circ} \mathrm{C}$. The plate was observed for any zones of inhibition (ZOI) around the well. The results were considered positive if the diameter $(\mathrm{mm})$ of the ZOI was greater than $1 \mathrm{~mm}$.

Identification of probiotic strains : Probiotic strains with positive antagonistic activity against the pathogens were cultured in a MRS broth for $24 \mathrm{hrs}$ and centrifuged at $15,000 \mathrm{xg}$ for $2 \mathrm{~min}$ to obtain a pellet. The pellet obtained was used for DNA extraction using a DNA extraction kit (Promega, Madison, WI, U.S.A.) following the manufacturer's protocol. Following DNA extraction, bacterial 16S rDNA gene was amplified using $8 \mathrm{~F}$ (5'AGAGTTTGATCCTGGCTCAG $3^{\prime}$ ) and 1492R (5' CGGGAACGTATTCACCG 3') primers for amplification using Polymerase Chain Reaction (PCR). Product quality was verified through electrophoresis and analyzed using 1.5\% agarose gel stain with sybr safe, then sequencing was sent to $1^{\text {st }}$ Base Company. The obtained $16 \mathrm{~S}$ rDNA gene sequences were added to publically available bacterial $16 \mathrm{~S}$ rDNA sequences and were integrated to the database with the automatic alignment tool in Chromas software. A phylogenetic tree was generated by 
performing a distance matrix analysis using neighbor joining method in Mega 6 Software (Tamura et al., 2013). A database search and comparisons were done with BLAST search.

\section{Results and Discussion}

The use of strong antimicrobial chemicals, including antibiotics, is becoming increasingly regulated in disease treatments and thus, more environmentally friendly options are required. Alternatives to such probiotics may be a better choice over antibiotics (Cruz et al., 2012). The demand for the probiotics is growing larger due to the increasing demand for hygienic and environmentally friendly products (Wang et al., 2008). In this study, 14 probiotics strains from the gastrointestinal tract of healthy freshwater prawns, $M$. rosenbergii, were identified.

Table 1 shows the antimicrobial activities against three pathogens. As shown in Table 1, strain no. 2, 9 and 12 had inhibitory effects against all the three pathogens tested. On the other hand, 8 strains (no. 3, 13, 16, 20, 27, 30, 31 and 33) showed inhibitory effects against both Vibrio spp. Strain no. 18 and 39 showed inhibitory effects on $V$. alginolyticus only, whereas strain no. 17 had inhibitory effects against $V$. parahaemolyticus only.

Molecular identification of the strains was performed by amplifying and sequencing the 16S rRNA gene sequences and comparing the results to the database of known 16S rRNA gene sequences. As shown in Fig. 1, the results of the identification showed that the 14 isolated strains belonged to Enterococcus faecalis, Lactococcus lactis and Lactococcus garvieae. Enterococcus faecalis have antagonistic activity against many pathogenic bacteria. According to Allameh et al. (2017), isolation of $E$. faecalis from intestine of snakehead fish, Channa striatus showed high inhibitory effect against pathogens; A. hydrophila, Pseudomonas aeruginosa and Shewanella putrefaciens when tested by well diffusion method. On the other hand, the colonization of $E$. faecalis with $C$. butyrium, B. mesenteries and $L$. sporogenes in prawn gut improved the survival and growth of $M$. rosenbergii postlarvae (Jayanthi et al., 2015). This proved that $E$. faecalis is a potential probiotic and portrays an important role in improving the host defense mechanism against bacterial infection (Allameh et al., 2017). Besides, L. lactis are used in aquaculture industry in order to prevent cultured species from pathogenic bacteria (Balcazar et al., 2009).

The growth of several pathogens such as A. hydrophila and $V$. alginolyticus have been inactivated by candidate probiotics, isolated from the gastrointestinal tract of the host (Vine et al., 2004). Probiotics in vivo can produce antimicrobial metabolites, and therefore can serve as prophylactic and therapeutic agents (Vine et al., 2004). Probiotics can be used to

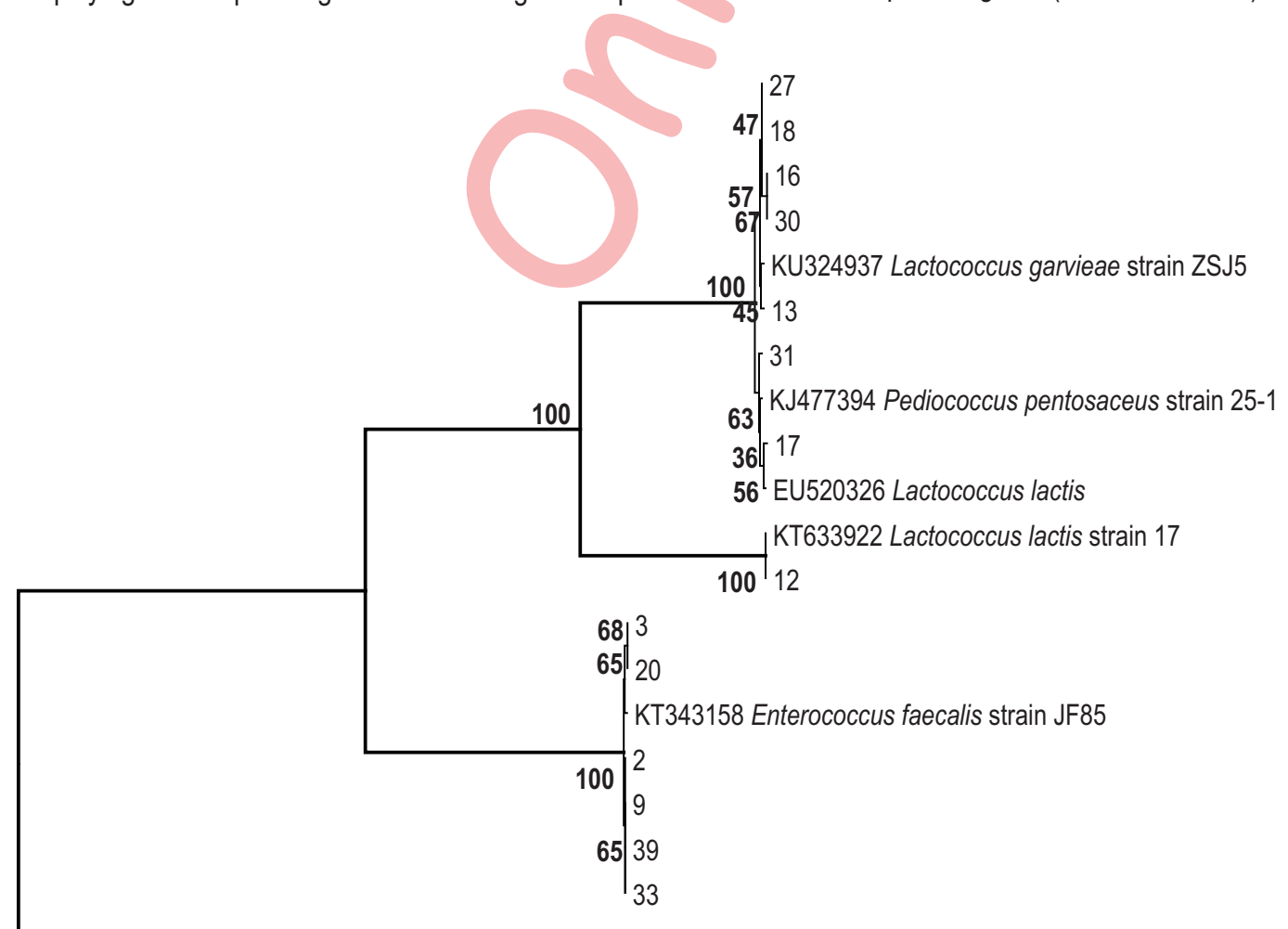

NR043437 Bifidobacterium longum subsp. infantis strain ATCC 15697

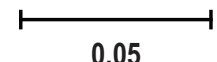

Fig. 1 : Phylogenetic neighbour-joining tree deduced from analysis nucleotide sequences of isolated bacteria 
Table 1 : Antimicrobial activities of 14 strains against various pathogens Clear zones: +: inhibition formed; -: no inhibition by well diffusion method

\begin{tabular}{llll}
\hline \multirow{2}{*}{ Strains } & \multicolumn{3}{c}{ Growth of inhibition of pathogens } \\
\cline { 2 - 4 } & V. parahaemolyticus & V.alginolyticus & A.hydrophila \\
\hline 2 & + & + & + \\
3 & + & + & - \\
9 & + & + & + \\
12 & + & + & + \\
13 & + & + & - \\
16 & + & + & - \\
17 & + & - & - \\
18 & - & + & - \\
20 & + & + & - \\
27 & + & + & - \\
30 & + & + & - \\
31 & + & + & - \\
33 & + & + & - \\
39 & - & + & \\
\hline
\end{tabular}

restrain the bacterial pathogens in fish and shrimp hatchery (Panigrahi et al., 2005; Balcazar et al., 2009; Ng et al., 2014). Based on positive results of this study, Lactococcus lactis, Enterococcus faecalis and Lactococcus garvieae should be further studied in feeding trials to investigate the effects of these probiotic bacterial on growth performance and immune response in M. rosenbergii.

\section{Acknowledgment}

This research was funded by the Ministry of Higher Education Malaysia through grant of Fundamental Research Grant Scheme (FRGS) to Dr. Md. Abdul Kader (Grant No. 59322)

\section{References}

Allameh, S.K., E. Ringo, F.M. Yusoff, H.M. Daud and A. Ideris. Dietary supplement of Enterococcus faecalis on digestive enzyme activities, short-chain fatty acid production, immune system response and disease resistance of Javanese carp (Puntius gonionotus, Bleeker 1850). Aquacult. Nutr., 23, 331-338 (2017)

Balcázar, J.L., I.D. Blas, I. Ruiz-Zarzuela, D. Cunningham, D. Vendrell and J.L. Muzquiz: The role of probiotics in aquaculture. Vet. Microbiol., 114, 173-186 (2006).

Balcázar, J.L., D. Vendrell, I. de Blas, I. Ruiz-Zarzuela and J. L. Múzquiz: Effect of Lactococcus lactis CLFP 100 and Leuconostoc mesenteroides CLFP 196 on Aeromonas salmonicida infection in brown trout (Salmo trutta). J. Mole. Microbiol. Biotechnol., 17, 153-157 (2009).

Cruz, P.M., A.L. Ibanez, O.A. Monroy Hermosillo and H.C. Ramirez Saad: Use of probiotics in aquaculture. ISRN Microbiol., 2012, doi:10.5402/2012/916845.

FAO/WHO: Report of a joint FAO/WHO expert consultation on evaluation of health and nutritional properties of probiotics in food including powder milk with live lactic acid bacteria, Co'rdoba, Argentina (2001).

FAO: Cultured Aquatic Species Information Programme. Macrobrachium rosenbergii. Cultured Aquatic Species Information Programme. Text by New, M. B. In: FAO Fisheries and Aquaculture Department [online]. Rome. (2004-2016).

Hai, N.V., R. Fotedar and N. Buller: Selection of probiotics by various inhibition test methods for use in the culture of western king prawns, Penaeus latisulcatus (Kishinouye). Aquaculture, 272, 231-239 (2007).

Irianto, A. and B. Austin: Probiotics in aquaculture. J. Fish Diseas., 25, $633-642$ (2002).

Jayanthi, L., P.S. Bhavan, V. Srinivasan, T. Muralisankar and N. Manickam: Dietary supplementation of probiotics product (ViBact*) on the survival, growth, biochemical constituents and gut microflora of the giant freshwater prawn Macrobrachium rosenbergii post-larvae. Asian J. Biochem. Pharm. Res., 5, 67-88 (2015).

Kesarcodi-Watson, A., H. Kaspar, M.J. Lategan and L. Gibson: Probiotics in aquaculture: The need, principles and mechanisms of action and screening processes. Aquaculture, 274, 1-14 (2008).

Muralisankar, T., P. Saravana, S. Radhakrishnan, C. Seenivasan, N. Manickam and R. Shanthi: Effects of dietary supplementation of fish and vegetable oils on the growth performance and muscle compositions of the freshwater prawn Macrobrachium rosenbergii. J. BasicAppl. Zool., 67, 34-39 (2014).

Nakano, T.: Microorganism. In: Dietary supplements for the Health and Quality of Cultured Fish. CAB International, London, UK, 2007.

Ng, W.K., Y.C. Kim, N. Romano, C.B. Koh and S.Y. Yang: Effects of dietary probiotics on the growth and feeding efficiency of red hybrid tilapia, Oreochromis sp., and subsequent resistance to Streptococcus agalactiae. J. Appl. Aquacult., 26, 22-31 (2014).

Panigrahi, A., V. Kiron, J. Puangkaew, T. Kobayashi, S. Satoh and H. Sugita: The viability of probiotic bacteria as a factor influencing the immune response in rainbow trout Oncorhynchus mykiss. Aquaculture, 243, 241-254 (2005).

Schrezenmeir, J. and M. De Vrese: Probiotics, prebiotics, and synbiotics - approaching a definition. Amer. J. Clinic. Nutri., 73, 361S-364S (2001).

Tamura, K., G. Stecher, D. Peterson, A. Filipski and S. Kumar: MEGA6: Molecular evolutionary genetics analysis version 6.0. Mol. Biol. Evol., 30, 2725-2729 (2013)

Vaseeharan, B., J. Lin and P. Ramasamy: Effect of probiotics, antibiotic sensitivity, pathogenicity and plasmid profiles of Listonella anguillarium - like bacteria isolated from Penaeus monodon culture systems. Aquaculture, 241,77-91 (2004).

Verschuere, L., G. Rombaut, P. Sorgeloos and W. Verstraete: Probiotic bacteria as biological control agents in aquaculture. Microbiol. Mol. Biol. Rev., 64, 655-671 (2000).

Vijayan, K.K., I.S. Bright Singh, N.S. Jayaprakash, S.V. Alavandi, S. Somnath Pai, R. Preetha, J.J.S. Rajan and T.C. Santiago: A brackishwater isolate of Pseudomonas PS-102, a potential antagonistic bacterium against pathogenic vibrios in penaeid and non-penaeid rearing systems. Aquaculture, 251,192-200 (2006).

Vine, N.G., W.D. Leukes, H. Kaiser, S. Daya, J. Baxter and T. Hecht: Competition for attachment of aquaculture candidate probiotic and pathogenic bacteria on fish intestinal mucus. J. Fish Diseas., 27, $319-326$ (2004).

Wang, Y.B., Z.Q. Tian, J.T. Yao and W.F. Li: Effect of probiotics, Enteroccus faecium on tilapia (Oreochromis niloticus) growth performance and immune response. Aquaculture, 277, 203-207 (2008). 